\title{
The Middle Voice in Eckhart and Modern Continental Philosophy
}

\section{Abstract:}

The recurring narrative of the relinquishment of human will animates the spiritual discourses of almost every mystical tradition. But contemporary discussions of spirituality gravitate towards exasperation when acknowledging the radical impotence of human agents, while much modern philosophy has found itself unable to think beyond the aporia of freedom and determinism.

The ability to mediate between total subjective autonomy and radical dissolution in God is vital if we are to avoid the dualism that Meister Eckhart subverts with his conception of detachment (gelassenheit). Heidegger takes up the terminology of Eckhart here, but provides a more philosophically astute sense of releasement. This article argues that both Heidegger and Eckhart draw upon the middle voice, an ancient linguistic mode that places agency between activity and passivity. By uncovering traces of the middle voice, I propose that philosophy and theology bear with a grammatical cleavage that constitutes our experience of the world.

Keywords:

Eckhart, Heidegger, Ricoeur, Derrida, middle voice

In an early work, the Talks of Instruction, Meister Eckhart has this to say: "The most powerful prayer, one well-nigh omnipotent to gain all things, and the noblest work of all is that which proceeds from a bare mind" (Eckhart, 1987, p. 12). For some people Eckhart's conception of prayer can seem remote, barren, or elitist with its call to abandon intercession and petition (Mills, 1996). It seems that only negation can 
constitute the appropriate attitude towards God, which is almost to say that the adoption of any attitude or orientation is a failure in relation to that to which there can be no relation. We might be left wondering what approach we are to take. Later, in the poem 'Granum sinapis' Eckhart has the following advice for those exploring the path to God: Leave place, leave time Avoid even image!

Go forth without a way

On the narrow path, Then you will find the desert track (Quoted in McGinn, 2001, p. 114).

Modern interpreters have often taken Eckhart to mean that we abandon paths, images and our own individual will by aligning ourselves with the greater will of God, and that this must be what Eckhart is getting at with his ideas of detachment and becoming nothing (Eckhart, 1981, p. xiv). This conventional interpretation is rejected by Denys Turner, and, less directly, by Eckhart himself (Turner, 1998, chapters 6 and 7). One key concern of this essay will be to develop a new context in which to consider the more radical conception of detachment that Eckhart has in mind, namely the linguistic middle voice.

In this essay I will argue that the recurring narrative of the relinquishment of individual will is too often interpreted within the horizon of a polarised conception of agency. This polarisation emerges as the opposition between an individual human will, and God's divine will, and from the perspective of this general structure, one pole will tend to dominate. We might imagine ourselves to be at varying degrees along this axis as we move closer or further from the ground of our being. We may even regard an identification of ourselves with the divine element within as the supreme goal of the religious life. This narrative of spiritual development is common these days within the 
context of spirituality, broadly conceived. But I want to suggest that the tension implicit within this narrative expresses a metaphysical commitment that is constituted in the linguistic structures of many modern languages, a structure that encourages a misreading of Eckhart, as well as the Christian mystical tradition in general (to say nothing of a similar misinterpretation of central insights within a number of other world religions).

So this essay contemplates the force of logic within the structure of prevailing discourse and language. The force of that logic is derived from an assumption of binary opposition, an opposition fundamental to the structures of theological understanding. In Biblical hermeneutics we see this structure represented in the idea that what is not exegesis, reading out, must fall within the category of eisegesis, reading in. In the hermeneutics of divination, for example in astrology, the process of speculative reading through the casting of horoscopes, crosses over into a symbolism which allows for the given realisations that constitute the work of divination (Cornelius, 2003, chapter 15). A further example can be found in the three stages of orison, of medieval prayer, which describes a path from recollection, through quiet, and into contemplation likewise charting the transition between the active and the passive (Underhill, 2002, p. 306). Despite these and other examples, religious insight is often regarded in terms of either something realised or revealed, as something speculative or projected. The force of logic within this duality expresses an anthropology in which human agency is called to submit to divine will, by a path of self-abnegation, an apophatic anthropology.

I will argue that the philosophy of Martin Heidegger offers an opportunity to think outside the polarisation of agency just described. Heidegger's philosophy of language is central to his later ontology, and his use of poetic discourse synthesises the central significance of linguistic forms within philosophy, with the collapse of the kind 
of Kantian subjectivity that seems to preclude the nuanced agency that I wish to consider. This conception of nuanced agency, that is neither an autonomous Kantian subjectivity nor a resigned passivity, expresses a 'structured capability, ${ }^{1}$ a 'conditioned freedom.' I regard the middle voice as an important linguistic figure that reflects this stage between activity and passivity. As postmodern theory has contended, theoretical constructions of identity are by no means committed to a clear post-Kantian autonomy, yet it has been convincingly argued that the pragmatic assumptions of moral attitudes and approaches take human agency to be a prerequisite, an idea famously developed by Peter Strawson (Strawson, 2008), and, in somewhat different terms, by Paul Ricoeur. Some conception of autonomy is part of our cultural DNA, and falls below the radar of postmodern thought. Yet there remains a general incapacity to account for that autonomy given the ascendency of ever more elaborate forms of determinism. Our inability to conceive of a nuanced, structured or distributed agency might be a reflection of our inability to announce the linguistic middle voice in most modern languages in anything other than simple reflexive forms (e.g. the boy washes himself). In order to elaborate this thesis, I will outline a basic understanding of the middle voice and show how its employment would more faithfully reflect our actual being in the world. I will go on to consider to what extent Ricoeur, Derrida and finally Heidegger have employed this form in their attempts to articulate human agency and identity.

\section{The Middle Voice}

While ready definitions of the middle voice remain elusive (Andersen, 1994, p. 10; Eberhard, 2004, p. 9), speaking generally we can say that modern languages tend to rely only on the active and passive voice. The sentence 'the student writes the essay' clearly 
indicates the active agency of the student. Alternatively, we might have said that 'the essay is written by the student'. Here the passive voice is engaged and the essay is promoted to the subject being written, and it is this basic grammatical structure that designates the relation between subject and action, known as the voice or diathesis. But what about those precious times when we might say that essays write themselves? Many of us will have experience of creative moments where our activities require attention and engagement, but which somehow seem, at least on some level, to do themselves. In these moments we are in some sense both active and passive. We are taken up into the creative act. Poets and artists commonly describe their relation to the work of art in terms of a form of passive activity, or less commonly, active passivity. Michelangelo offers us a clear example where he suggests that the statue emerges from the marble. His role as the artist is as midwife to the sculpture which is born, or released, from the material. And so it is this domain of attentive responsivity, epitomised by certain Renaissance figures, which calls for the expression of the middle voice. Or perhaps we should better say that the withdrawal of the middle voice in modern languages reflects the sedimentation of the Cartesian and Kantian subjectivity that constitutes the autonomous agent of modern metaphysics.

Consequently we might not be surprised to discover that some ancient languages (Sanskrit, Ancient Greek and Indo-Persian) employ the middle voice to express an event that we could say engulfs subject and object. However, Roland Barthes' suggestion that the application of the middle voice is anterior to the emergence of the subject/object polarity seems more plausible (Barthes, 1989, pp. 17-21). The structure of ancient Greek - particularly Aristotelian - thinking, presents human making as a fostering of what nature grants, a bringing-forth of things into their own nature. Thus nature's own intentionality is creatively borne in the event of poiesis - or bringing forth (Dupré, 
1993, pp. 22-29). The teleological structure of Greek ontology is entirely consistent with its linguistic adherence to the middle voice, since intentionality resides not only within the interested subject, but the cosmos itself is replete with an order akin to intentionality.

Reflecting this cosmology, ancient Greek employs a number of forms of the middle voice from relatively clear reflexive usage, such as "the cat cleans itself", to more complex constructions such as causative, permissive and deponent middle voices, the details of which need not detain us here. For a long time these forms have exercised New Testament interpretation, from which many examples could be cited. ${ }^{2}$ Acts 22:16 says, for example, "Rise, have yourself baptized and allow your sins to be washed away" (Wallace, 1996, pp. 426-427). Religious rituals provide probably the best examples of the intermingling of activity and passivity that characterizes the middle voice. Clearly the religious act cannot be complete if it simply expresses the determinate agency and will of the autonomous subject - we cannot simply cleanse ourselves. Yet, as beings endowed with free will, we do not entirely forego human agency even (or especially) where that agency is called into submission. For better and for worse, every truly theological endeavor is a combination of divine revelation as well as human figuration, or as Paul Ricoeur says, of manifestation and proclamation (Ricoeur, 1995). ${ }^{3}$ And the crisis of modernity arises in no small part due to our incapacity to distinguish between the two. But this incapacity turns out to be a saving power also, for it is this space between seeking and finding that seems faithful to the most profound experiences of human existence.

In contrast to the understanding within ancient Greek, the middle voice is not easily heard in modern English, though traces are to be found on bumper stickers which declare that 'Stuff Happens' or phrases such as 'I find myself in agreement' and 'it 
occurs to me'. We normally speak of something occurring to us when we are engaged in some kind of active thinking process. While we know ourselves to be actively doing something, we also appreciate that when something occurs to us, it presents itself as a gift. It is this gift character, and our capacity to properly receive what is given in it, that we know immediately to be neither simply active nor passive. The ambiguity of this gift character also resonates in the rather curious English phrase "the girl fell pregnant", or "I've fallen pregnant!", which does not denote only unplanned pregnancy, but rather seems to indicate that we are given to a process in which we are clearly both active and passive. These moments of grace, as we might call them, raise again the theological ground in which, I want to suggest, our freedom can be properly expressed. In the terms of Eckhart, it is only through a gift of grace that the soul can find its way towards the divine light, yet only within that movement towards God is the soul free of the bonds of exterior life:

As God is the Prime Mover of nature, so also He creates free impulses towards Himself and to all good things. Grace renders the will free that it may do everything with God's help, working with grace as with an instrument which belongs to it. So the will arrives at freedom through love, nay, becomes itself love, for love unites with God (Eckhart, 2001).

This kind of participative freedom is only properly conceivable within a theological context since therein we discover the established order in which freedom can be granted. In order to further contextualise and clarify the question of agency in modern philosophy I now turn to Paul Ricoeur.

\section{Paul Ricoeur and the Crisis of Subjectivity}


In many ways, Ricoeur would be the obvious thinker with which to seek philosophical clarification of the middle voice, given his interest in exploring the interface between philosophy and theology. His desire to hold in creative tension many oppositions, also commends his thinking to the present question. Ricoeur's mediations, of history and truth, ideology and utopia, hermeneutics and phenomenology, show a pattern in which what is given universally can only be disclosed within the particular manifestation of the historical moment. Although I have been unable to find any explicit discussion of the middle voice in Ricoeur, I think it worthwhile to turn to his conception of subjectivity and agency.

For Ricoeur, the modern subject is a derivative notion whose autonomous freedom to act can only be established at the price of displacing the context in which action is structured. Ricoeur's philosophical anthropology does not allow for such a displaced subjectivity. Yet, Ricoeur observes, modernity seems to have left us with an unsatisfying choice between acknowledging the absolute freedom of the Cartesian foundationalist self, and accepting the Nietzschean deconstruction leaving us nothing other than a rhetorical self - rhetorical in the sense that its existence as a foundational moment of subjective identity, turns out to be nothing more than a insubstantial rhetorical strategy. The foundationalist self is free to act autonomously, as if selfdetermining. But as Nietzsche's deconstruction of the self has unfolded, that self has become increasingly "humiliated" (Ricoeur, 1992, p. 16). We are left with a rhetorical self whose capability to act seems critically undermined. Ricoeur's later work has been committed to mediating the polarity between the foundational and rhetorical self such that a choice between them turns out to be false. Clearly the effort to constitute an 
authentic identity for the self is intimately associated with the question of human agency.

It must be emphasised that Ricoeur is committed to an ontology of human agency. We are capable beings and we do act in the fullest sense. However, from the perspective of modern explanatory accounts, typical of the natural sciences, we are able to observe a series of elements that structure human action from social and cultural influences, to biological and even neurological determinations. According to Ricoeur, recent action theory has generally considered actions from the perspective of a “something that occurs" (Ricoeur, 1992, pp. 60-61; van den Hengel, 2002, p. 75). There is a pressure to conceive of any occurrence in objective terms, namely as an event rather than an action. ${ }^{4}$ Consequently, unless we revert to a Cartesian foundationalism, what we generally call actions are in danger of becoming only events since there can be no access whatsoever to the agency which defines the occurrence as an action. These events are objective observable entities that do not depend upon an analysis or appearance of the "who" - the subjective agent.

From this point of view it might seem like a remarkable fact that analytic philosophy has not fallen, more generally, into an irremediable determinism. To be sure, analytic theories of action are concerned with intention and motivation, so why do we not discover the core of identity and of capability within these intentions? The problem here is that it is quite possible that such intentions and motivations are themselves organized by principles that are no less vulnerable to further explanation. The space left for the irreducible identity of human agency cannot be secured or guaranteed. Every level of life seems explicable in terms potentially, if not actually, available to scientific explanation, and those who wish to maintain a notion of radical freedom in the midst of these explanatory paradigms, begin to look rather like nineteenth or twentieth century 
theologians who dogmatically defend their majestic divinity between the gaps left by the latest scientific theory (e.g., God of the gaps). The notion that there might be a kernel of free agency that cannot be observed in terms of any exterior motivation has no basis in analytic explanation, and can only rest upon a Cartesian foundationalism. From this perspective, it seems that the implications of the "death of the subject" have yet to be fully unfolded. But what of the compatibilist views? The attempts of compatibilists to overcome the duality of agency and determinism, without reduction or negation, too often seem to postpone the question of the phenomenology of agency, and allow the free act to occur only because of the assent of a more deeply determined motivation. ${ }^{5}$

The real tension of the aporia becomes apparent when we consider indeterminacy as the alternative to determinism. As many philosophers have pointed out, indeterminacy provides no stronger ground for agency than determinism (McGinn, 1993, p. 81; Strawson, 1986, p. 25). If determinism argues that our actions are, to quote Colin McGinn, "uniquely necessitated by prior states of the world, just like every other event" (McGinn, 1993, p. 81), then there is no such thing as genuine action, there are only events. On the other hand, indeterminacy simply suggests that a force of randomness is responsible for the event. Again, there is no action here, only a random occurrence, an event. Calling upon the notion of indeterminacy does not provide the libertarian with any foundation on which to place the autonomous self. Is it the polarized discourse of active/passive that has resulted in this impasse? Could the linguistic figure of the middle voice provide a way forward? Although Ricoeur does not explicitly refer to the linguistic middle voice, his response certainly evokes a middle discourse.

For Ricoeur, the moment of perceiving the action of the agent can take place, but it cannot be taken as a foundational moment. Ricoeur uses the term attestation to 
distinguish this moment in which something is somehow known through a direct understanding and affirmation (1992, pp. 21-23). We know ourselves to be free agents that make choices though there is no ground for that knowledge in purely explanatory terms. To say that 'we know' ourselves to be agents is not quite faithful to Ricoeur who wishes rather to indicate that we testify to our own self-understanding (and understanding of others) as agents throughout life itself. The testimony is sufficient but only if we recognize that this attestation does not offer an invulnerable ground for the self. It is, rather, an unverifiable confidence in human capability that requires both understanding as well as explanation. It is, then, open to alterity, and therefore, to reinterpretation. The same unverifiable confidence offers us the possibility of relating to the other, an other which, analytically speaking, must remain transcendent, and thereby unknowable, even impossible.

Attempts to account for the ghost in the machine do not necessarily withstand the analytical approaches to subjectivity. Ricoeur prefers to speak of a narrative identity arising out of an "intuitive apprehension" (1992, p. 114, n. 1), an apprehension in which the story of the self is the mediation of self-identity, and presence of alterity. As Ricoeur says, "there is no self-understanding that is not mediated by signs, symbols and texts" (1991, p. 15). In speaking of the narrative self constructed within the engagement between oneself and another, Ricoeur is clearly evoking a middle term. It is, perhaps, surprising that Ricoeur does not make explicit discussion of a philosophy of the middle voice. Let us now briefly turn to Derrida, a thinker who appears to engage more explicitly with the middle voice.

\section{The Middle Voice in Derrida}


My approach here is largely informed by Catherine Pickstock's interpretation of Derrida in her book After Writing. Here Pickstock is not convinced by Derrida's interpretation of Plato's Phaedrus, and offers instead a clear expression of Plato's intimations of the middle voice in understanding the role of eros in the Socratic gaze. Pickstock argues that Derridean différance does not successfully exceed the contrast between active and passive, and so fails to orient us to genuine mystery. It is worth recalling that Derrida's conception of différance represents the attempt to defer the consummation or closure of the meaning of a signifier or text. Justice, to take a paradigmatic example, continually interrupts law, leading to the endless deferral of a state of genuine legislated peace. So the differentiation of opposition implies an endless cycle of displacement which is différance. For Pickstock, what this process amounts to is a suppression, rather than attenuation, of agency (1998, pp. 116-117). Pickstock says,

Derrida's qualification of the autonomous subject, via the removal of all elements of choice, intention, desire, and particularity from the speaker or writer, does not mean that différance is in the middle voice, for rather than mediating all divine via human action, it merely forces the speaker into a situation of double passivity, both unable to choose language (rather, chosen by it), and unaware of this passivity (1998, p. 36).

Derrida is unable to announce the middle voice apart from the context of the continually differentiated undecidable that results only in a violent suppression of agency and of subjectivity. To put this in a broader context, Pickstock contrasts Derrida's failure to escape the duality of active/passive and the violence implied within it, with Plato's "outwitting of the duality" (1998, p. 36) through the role of eros. In the Phaedrus, Socrates explores the double-vision implied in the erotic gaze in which empirical sight 
is made possible within the movement of recognition or recollection. By its capacity to subordinate itself to that upon which it looks, this erotic phenomenon is neither active nor passive, rather the participation of both is the precondition of any sight at all. Associating this participation with subjectivity Pickstock says, "This gaze does not arise from an autonomous subject, but by the ambiguous action/passion of recognition, becomes a gaze which receives into itself that which offers itself to be recognised" (1998, p. 32). As was suggested earlier, this participative ontology is very much a part of Greek thinking, and Pickstock is seeking to restore our sensitivity to its significance. More fundamentally, there is a concern to undercut the violence of the dualist order that imposes itself throughout the history of philosophy, a dualism that is not avoided by the medial undecidability of différance which renders both agency and object impossible.

For Pickstock the middle voice rests upon the kind of participative ontology that Derrida would reject, but that seems central to Heidegger's approach. The degree to which this participative ontology is theological in nature must remain an open question at this stage, though, I would suggestively ask in what does participation participate if not some divine order? Despite the fact that Heidegger is well-known to be sceptical of explicitly theological discourse, it is clear that he evokes this participative ontology by exploring the space between activity and passivity, for example where he speaks of real thinking as a response to what calls for thinking, or what gives itself to be thought (Heidegger, 1968). So it is to Heidegger that we now turn.

\section{The Middle Voice of Heidegger}

My interest in Heidegger's use of the middle voice first arose in attempting to understand why Heidegger's commentators often take his questioning of technology to 
be an expression of technological determinism or fatalism. To put it briefly, philosophers have often rejected Heidegger's analysis of technology on the grounds that it is both essentializing and fatalistic, and that consequently we are left helpless before the destiny of modern technology (Thomson, 2005, pp. 47-52; Feenberg, 1999, p. 1417). The perceived fatalism consists in the concealment both of the technological disclosure of being, as well as the fact that it is us who disclose being technologically. We are slaves to a technological rationality that we ourselves are engaged in, and it is our passionate and intensifying technological engagement that makes us blind to the fatalism behind technological enframing.

This reading of Heidegger is unhelpful for many reasons, but mainly, I think, because it rests upon an anthropology - and an associated conception of agency - that is fundamentally opposed to the dynamics of Heidegger's philosophical project. Heidegger's question of being remains fundamentally anthropological throughout his career and although in his later work he abandons the language of Dasein, clearly the mutuality of being and human-being is essential to his thought, a mutuality that is centrally concerned with the will. So developing a nuanced conception of agency is vital if we are to understand the threat of technological rationality, without the resignation that might seem to follow.

Heidegger's language often recalls the middle voice, both in his appropriation of common German expressions such as 'es gibt', literally meaning 'it gives', and in his own creative aphorisms such as 'die Sprache spricht', translated as 'language speaks' (Heidegger, 1975, p. 124). Heidegger's interest in, and employment of, these linguistic forms is central to his philosophical destruction of metaphysics and his attention to the question concerning technology. Some commentators have noted the profound unity that exists in Heidegger's thought despite the influential interpretation that sees 
Heidegger to have turned during the 1930's from phenomenological analysis to what he later calls 'thinking' (Richardson 2003; Thomson 2005). What these commentators note is the unity to be found in Heidegger's hermeneutical approach described, particularly by Rojcewicz, in terms of disclosive looking. ${ }^{6}$

Disclosive looking expresses the sense in which the self-showing of Being always involves the partnership of human being. Being shows itself in terms of the disclosive looking of human beings, what Rojcewicz calls "the active reception of the self-offering of Being” (2005, p. 55). Heidegger's analysis of the technological age suggests that a particular form of Being's self-showing and human being's disclosive looking has become predominant. It is a looking, or revealing, that places the world at the disposal of human being. Thus Heidegger states:

The revealing that rules in modern technology is a challenging, which puts to nature the unreasonable demand that it supply energy that can be extracted and stored as such... a tract of land is challenged into the putting out of coal and ore. The earth now reveals itself as a coal mining district, the soil as a mineral deposit (1977, p. 13).

The earth, says Heidegger, reveals itself as resources for human consumption. It is not simply the case that human beings disclose the earth in terms of resources. Nor are human beings inactive in this disclosure. They are the agents doing the disclosive looking' but equally, they are the passive agents, in receipt of Being's self showing as resource. In contrast to technological revealing, Heidegger's famous image of the jug that gathers the fourfold does so through a providential act, an act achieved not simply by the maker, or by the jug itself, but by the gathering that is made present in the unity of the jug and the world (1975, p. 171). 
But interpretations of Heidegger's writings on technology often tend to place his analysis in support either of human activity or passivity. Consequently we are often faced with the interpretation that we are subject to Being's self-showing as technology determines it. And, as I suggested earlier, Heidegger's talk of the destiny of technology seals his fate as a technological determinist. Heidegger's language may not always be clear, but I believe this to be a reflection of his orientation to a space between the active and the passive, namely the middle voice which as we have noted, generally does not belong to modern European languages. Thus Heidegger says:

Always the destining of revealing holds complete sway over man. But that destining is never a fate that compels. For man becomes truly free only insofar as he belongs to the realm of destining and so becomes one who listens and hears, and not one who is simply constrained to obey (1977 p. 25).

Our general conception of freedom seems confined by this notion of a realm of destining despite Heidegger's attempts to distance it from constraint or compulsion. However, the middle voice can express the sense in which our freedom is constituted in relation to what is given, and so structuring or constituting elements can be located within such a realm.

So I am suggesting that the middle voice plays a foundational role in Heidegger's philosophical project. This is clearly part of Heidegger's grounding in phenomenology which seeks to undercut the duality of subject and object. It is the framing of Being in terms of subject and object that calls Heidegger to repeatedly raise the question of Being. Where Being is conceived as objects and subjects, the originary phenomenon, which, as Heidegger puts it in Being and Time "shows itself in itself" (1996, p. 25) ${ }^{7}$ is obscured. Thus the deconstruction of subjective metaphysics entails a deconstruction of the duality of activity and passivity. As Charles Scott says, "[b]oth the 
middle voice and its obscurity...produce or yield thought processes by which the subject-object structure is overcome" (1989, p. 753). While Scott offers an interesting analysis of the middle voice in continental philosophy, his suggestion that the subjectobject structure is to be 'overcome' might be accused of inverting the actual problem. As has already been suggested, the middle voice expresses a mode prior to the subjectobject structure. It is, then, less a case of overcoming than undercutting this structure, that is to say, of addressing the ground from which the subject-object structure emerges. The extent to which we are appropriated by subjective metaphysics is proportionate to the extent to which we are able to think outside of the domain of activity and passivity. This idea of thinking outside the domain of the will is fundamentally different from negation or submission of the will. Such negations or submissions remain within the economy of the will and are, to that extent, sublimations that serve merely to sustain, or even extend, the currency of wilful subjectivity. Where mystical theology rests upon the suppression of human will, it fails to radically undercut this structure. This is what makes Eckhart's call to abandon the will genuinely radical; his conception of detachment does not rest with the suppression or negation of the will, but makes the move to undercut entirely the structure of wilful subjectivity, a theme we will soon draw out, but not before we more clearly acknowledge the clarification that Heidegger makes.

We have seen that the attempt to think outside the domain of subjectivity can be correlated with Heidegger's call to think outside the domain of the will. In his study Heidegger and the Will, Bret Davis perceives a crucial difference in Heidegger's thinking between not-willing - as the simple negation of the will, and non-willing which indicates a fundamental attunement that is anterior to will (2007, p. 15; see also Llewelyn, 1991, p. 208-209). The former is a passivity or quietism that is opposed to the active assertion of the will, but itself requires some form of assent or resolve. This is 
clearly not the gelassenheit (releasement or detachment) of Heidegger, or of Eckhart. The latter is harder to define since our language frames thinking in terms already within this domain of the will. That is to say that the structure of the linguistic subject and object/predicate, mirrors the structure of the active and passive voice.

Rather than conceive the will as a faculty of human subjectivity, Heidegger tends to reverse this view by seeing subjectivity as an expression of the will. Heidegger refers approvingly to Schelling's reflections on the will, saying,

[t]he will in this willing does not mean here a capacity of the human soul, however; the word 'willing' here designates the Being of beings as a whole. Every single being and all beings as a whole have their essential powers in and through the will (1968, p. 91).

Drawing out the implications of Heidegger's appropriation of will, Davis asks the following leading question: "what if it were the case that thinking in terms of a subject who possesses faculties, a 'subject who wills,' already involves a particular wilful mode of being-in-the-world?" (2007, p. 6). Davis goes on to argue that for Heidegger the modern subject, who thinks by way of representations and who wills through volition, is very much a product of a more fundamental attunement to Being. Being outside the domain of the will, on the other hand, is not simply a human achievement, and might then, be best expressed within the middle voice. It is both something that appropriates us, as much as something we appropriate. It seems that a free relation to this basic attitude or attunement is possible insofar as we can be aware of its existence. And yet modern languages tend to disclose things in terms of the polarity that we have sought to interrupt. Little wonder that Heidegger's philosophy, which, as much as anything is a philosophy of language, so often seeks to excavate ancient Greek thinking. Consequently, so much of Heidegger's terminology can only really be expressed in 
what I loosely refer to as a middle discourse: terms such as appropriation (Enowning), unconcealment (Aletheia), event (Ereignis) and releasement (Gelassenheit); along with more dynamic expressions such as 'the thing things,' (1975, p. 181) and the 'region regions' (1966).

For Eckhart, particularly the later Eckhart, the possibility of God's will does not arise as we negate our own, just as the possibility of the disclosure of being in Heidegger does not correlate with the diminution of Cartesian subjectivity. Eckhart's radical suggestion is closer, structurally speaking, to Heidegger's effort to escape entirely the domain of the will - to non-willing. Eckhart's conception of freedom is not the negation of the will, but rather is found in the pure freedom of the soul in God, a freedom which escapes altogether the problematics of the will in modern philosophy. As Eckhart makes explicit in one of his bolder moments, "when I come to be free of will of myself and of God's will and of all his works and of God himself, then I am above all created things, and I am neither God nor creature, but I am what I was and what I shall remain, now and eternally" (Quoted in McGinn, 2001, p. 143). Denys Turner has persuasively argued that the nature of Eckhartian detachment is not to be conceived as an experience of self-abnegation or radical surrender of will. This is not least because such a conception of surrender views detachment within an experiential context wholly foreign to the concerns that animate Eckhart's writings. Detachment is not simply the "quietism of desire" (Turner, 1998, p. 179), because such a conception seeks a "psychological condition of desirelessness" (Turner, 1998, p. 181) which is simply the opposite of psychological desire, thus remaining structured within the economy of the will. To negate the will is still structured by the movement of the will. As Turner says: 
To be detached is not therefore to be desireless of creation in order to desire only God, nor is it to desire nothing at all, even God. Rather, it is to desire out of that nothingness of self and God, so that, from the security of this 'fortress of the soul' which nothing create can enter, we can desire all things with a desire truly divine, because it is desire 'without a why' $(1998,185)$.

Elsewhere Turner identifies this detached desire as "the restoration of desire to a proper relation of objectivity...or reverence for its object" (1998, p. 183). Here it becomes clear that neither simple affirmation nor negation is enough. What is called for is a more radical step in which desire accords with its object, a movement in which the agent is both passive and active. The poetical dimension of Eckhart and of Heidegger is, in part, an expression of the conservation of a middle discourse in which our speaking participates in what calls to be said, in which our desire corresponds to its object, and where intellect and thought arise as the participation in that which calls to be thought.

My speculative thesis has been to argue that a sedimentation of diathesis within language has taken place, resulting in the marginalisation, even elimination, of a central realm of human experience. I have identified this realm primarily with the linguistic middle voice, but also more loosely with what I have called a middle discourse. This radical thesis requires more working through than I have been able to offer in this essay. Indeed, I have employed the linguistic context partly as a vehicle on which to develop a more general thesis that this middle discourse is remarkable by its absence in modern thought, especially where thought turns to questions of agency, responsibility and decision. Or more specifically, that many discussions of freedom and agency take for granted an impossible choice that modern language leaves us with.

Furthermore, the structure of my argument could suggest a literal contradiction. In attempting to affirm my thesis, that the elimination of the middle voice prevents 
thinking in terms of conditioned freedom or structured agency, I could be criticised for failing to consider that the force of logic within the discussion would suggest that I would be unable to announce the very thesis I wish to propose! How can I speak of that which I allege to be lost from speech? How have I achieved the unsayable? Of course it is not simply unsayable, any more than it is simply sayable. The reader's capacity to see what is meant here depends upon the self-negating groundless ground of Kantian autonomy. It is for this reason that the reader is asked to take seriously the notion of a dynamic or movement along what Heidegger would call a path (that leads to a wholly unanticipated clearing), an image that Eckhart staunchly resists. What does unite Heidegger and Eckhart more clearly here is the participative dimension of what manifests in the realm of human existence. If, like Heidegger, we attend to what gives itself to be thought, then we will, as thinkers, be both active and passive. This is the mode of contemplation where true philosophy, in its participative guise, responds to the call of being, a call at once philosophical and theological.

\section{References}

Andersen, Paul Kent, 1994. Empirical Studies in Diathesis. Münster: Nodus Publikationen.

Barthes, Roland, 1989. The Rustle of Language. Translated by Richard Howard, University of California Press.

Blass, F., and Debrunner, A., 1961. A Greek Grammar of the New Testament and Other Early Christian Literature. Translated by Robert Funk, Chicago: University of 
Chicago Press.

Caputo, John D., 1982. Heidegger and Aquinas: An Essay on Overcoming Metaphysics. New York: Fordham University Press.

Caputo, John D., 1986. The Mystical Element in Heidegger's Thought. New York: Fordham University Press.

Cornelius, Geoffrey, 2003. The Moment of Astrology. Bournemouth: Wessex Astrologer.

Davis, Bret W., 2007. Heidegger and the Will: On the Way to Gelassenheit. Northwestern University Press.

Dupré, Louis, 1993. Passage to Modernity, New Haven and London: Yale University Press.

Duméry, Henri, 1968. Faith and Reflection, New York: Herder and Herder.

Eberhard, Philippe, 2004. The Middle Voice in Gadamer's Hermeneutics, Tübingen: Mohr Siebeck.

Eckhart, Meister, 1981. Meister Eckhart: The Essential Sermons, Commentaries, Treatises, and Defense. Translated by Edmund Colledge and Bernard McGinn. New York: Paulist Press.

Eckhart, Meister, 1987. Meister Eckhart, Sermons and Treatises, vol. 3, Translated by M. O'C. Walshe Shaftesbury, Dorset, Element Books, 1987.

Eckhart, Meister, 2001. 'Outward and Inward Morality' Meister Eckhart's Sermons, Translated by Claud Field. Grand Rapids, MI: Christian Classics Ethereal 
Library. Available at http://www.ccel.org/ccel/eckhart/sermons.x.html, [Accessed 14 ${ }^{\text {th }}$ 2011].

Feenberg, Andrew, 1999. Questioning Technology, London: Routledge.

Giddens, Anthony, 1984. The Constitution of Society, Cambridge: Polity Press.

Heidegger, Martin, 1968. What is Called Thinking. Translated by J. Glenn Gray, Harper and Row.

Heidegger, Martin, 1969. Discourse on Thinking: A Translation of Gelassenheit. Translated by John M. Anderson and E. Hans Freund. New York ; London: Harper \& Row.

Heidegger, Martin, 1975. Poetry, Language, Thought. Translated by Albert Hofstadter, Harper and Row.

Heidegger, Martin, 1977. The Question Concerning Technology and Other Essays.

Translated by William Lovitt, Harper and Row.

Heidegger, Martin, 1996. Being and Time. Translated by Joan Stambaugh, New York: State University of New York.

Llewelyn, John, 1991. The Middle Voice of Ecological Conscience: A Chiasmic Reading of Responsibility in the Neighbourhood of Levinas, Heidegger and Others, London: Macmillan.

Mills, John Orme, 1996. 'Was Eckhart an Elitist?', Eckhart Review, Spring.

McGinn, Bernard, 2001. The Mystical Thought of Meister Eckhart, New York: Crossroad Publishing. 
McGinn, Colin, 1993. Problems in Philosophy, Oxford, Blackwell Publishers.

Pickstock, Catherine, 1998. After Writing: On the Liturgical Consummation of Philosophy, Oxford: Blackwell Publishers.

Richardson, William, 2003. From Phenomenology to Thought. New York: Fordham University Press.

Ricoeur, Paul, 1991. 'On Interpretation,' From Text to Action: Essays in Hermeneutics. Translated by Kathleen Blamey and John B. Thompson, Evanston: Northwestern University Press.

Ricoeur, Paul, 1992. Oneself as Another. Translated by Kathleen Blamey, Chicago: University of Chicago Press.

Ricoeur, Paul, 1995. Figuring the Sacred. Translated by David Pellauer, Minneapolis: Fortress Press.

Rojcewicz, Richard, 2006. The Gods and Technology. New York: SUNY Press.

Schopenhauer, Arthur, 2005. Essay on the Freedom of the Will. Dover Publications.

Scott, Charles E., 1989. 'The Middle Voice in Metaphysics', Review of Metaphysics 42:4.

Strawson, Galen, 1986. Freedom and Belief, Oxford: Oxford University Press.

Strawson, Peter, 2008. 'Freedom and Resentment', Freedom and Resentment and other Essays Abingdon: Routledge. 
Thomson, Iain, 2005. Heidegger and Ontotheology. New York: Cambridge University Press.

Turner, Denys, 1998. The Darkness of God: Negativity in Christian Mysticism, Cambridge: Cambridge University Press.

Underhill, Evelyn, 2002. Mysticism, New York: Dover.

Van den Hengel, John, 2002. 'Can there be a Science of Action?' in Ricoeur as Another: the Ethics of Subjectivity, Albany: SUNY Press.

Wallace, Daniel, 1996. Greek Grammar Beyond the Basics: An Exegetical Syntax of the New Testament. Michigan: Zondervan.

\footnotetext{
${ }^{1}$ In The Constitution of Society, Anthony Giddens has developed a sociological analysis of this kind of structured capability in his 'structuration theory' in which the agency of the individual is cast within the context of sociological structures. Those structures form a composite structure of capability in which individual freedom is located.

${ }^{2}$ Although linguists agree that Ancient Greek employs the middle voice, we should acknowledge the evidence which suggests that the middle voice was retreating from Greek during the New Testament period (Blass and Debrunner, 1961).

${ }^{3}$ Along similar lines the philosopher of religion Louis Dupre says, "Man's relation to the Absolute must be expressed in a number of representations, and even though these representations are not the ultimate object of man's faith, they are indispensable means for the spirit's union with the Absolute" (Duméry, 1968, p. xviii).
} 
${ }^{4}$ For Donald Davidson, actions should be classed as a subset of events which seems to endanger the ontology of action in the sense for which Ricoeur is arguing, (van den Hengel, 2002, pp. 77-78).

${ }^{5}$ The tradition of compatibilism is first developed by the Stoics, though modern forms are rooted in ideas that Schopenhauer encapsulated in his idea that, although we can do as we will, we cannot will as we will (Schopenhauer, 2005).

${ }^{6}$ Rojcewicz prefers 'disclosive looking' as a translation of Entbergen than Lovitt's original rendering as 'revealing'. For an illuminating explanation of Rojcewicz's choice (2006, pp. 47-55).

${ }^{7}$ Heidegger here explicitly refers to the Greek middle voice: "Phainesthai is a 'middle voice' construction of phaino, to bring into daylight, to place in brightness." 